\author{
https://doi.org/10.52449/1857-4114.2020.35-1.01
}

CZU: 37.026: 796.8 .81

\title{
GENERAL DACTIC AND SPECIAL PRINCIPLES IN THE GENERAL THEORY OF TRAINING HIGHLY QUALIFIED ATHLETES
}

\author{
Manolachi Victor ${ }^{1}$, ORCID: 0000-0002-3904-3564 \\ ${ }^{1}$ State University of Physical Education and Sport, Chisinau, Republic of Moldova
}

\begin{abstract}
This article presents an analysis of the well-known specialized literature on the issue of proper coverage of the problems of the state and development of specialized general pedagogical principles used in the training process of wrestlers of various sports styles, as fundamental in the qualitative mastering of the motor-technical potential for achieving higher sports mastery. This analysis compares the substantive aspects on this issue in various sources and evaluates their significance for the practice of the training process.

Keywords: sports wrestling; specialization; general didactic principles; training process; types of sports wrestling; sports improvement; modern stage; literary sources; modern authors; methods and means; physical training; structure of the training process; power qualities.
\end{abstract}

Introduction. The study of the content of the overwhelming majority of fundamental works (monographs, textbooks, teaching aids on wrestling) reflects a very limited approach to the foundations of the rational construction of sports training, the lack of proper reliance on a wide volume of empirical knowledge in the field of both the theory and methodology of sports training, and a number of related disciplines (anatomy, biomechanics, biochemistry, physiology, sports medicine, etc.) and scientific approaches (systems approach, adaptation theory, theory of motion control, theory of functional systems, etc.), formalized in the form of special patterns and principles $[1,3,6,7,8,10,19]$. The rational process of sports training, including the theoretical and methodological provisions of strength training, is mainly based on the experience of advanced sports practice and general didactic principles accessibility, consciousness, activity, visibility, systematicity, consistency, strength $[3,4,5,9$, $11,15]$.

The aim. To determine, according to the studied literary sources, the degree of development, illumination, importance and orientation of the application of the fundamental didactic and special principles in the practice of wrestling - accessibility, consciousness, activity, visibility, systematicity, consistency, strength.

\section{Tasks:}

1. To study the available specialized publications of scientists-authors on various types of wrestling about the degree of development, illumination and the importance of applying fundamental didactic and special principles in training practice.

2. To determine the most significant literary sources of scientists, in which, in an accessible form, the illumination and pedagogical significance of the fundamental didactic and special principles for the effective mastering of training means in the sportstraining process were emphasized and analyzed.

\section{Organization of research.}

We have studied the available, fundamental information materials of a number of leading scientists on the effective use of special pedagogical principles in the 
training of athletes specializing in various sports, including wrestling.

\section{Results of the research and discussion.}

The state, development and application of general didactic principles in sports training of wrestlers of various types of single combats is focused on high-quality educational and sports training in various types of training $[2,12,13$, $14,16,17,18]$.

In sports, the process of long-term learning and training mainly occurs at a complex motor level and on the basis of the corresponding physiological, biomechanical, psycho-regulatory processes (Platonov, 2015). An additional difficulty is the fact that improvement in wrestling is focused on the maximum available levels of various aspects of training, motor qualities, manifestations of the psyche (Harre, 1971; Matveev, 1977; Platonov, 1977, 2004; Gaverdovsky, 2007; and others), as well as the implementation of huge loads associated with such concepts as stress, fatigue, overstraining of functional systems, overtraining, recovery, urgent and delayed adaptive effect, etc. (Shirkovets, Shustin, 1999; Mackinnon, 2000; Meeusen et al., 2006; Kenney et al., 2012).

In these conditions, it becomes clear that general didactic principles, together with a wide amount of knowledge related to sports training, the practice of elite sports, related disciplines and approaches, are the basis for the formation of special patterns and principles, that is, didactics of the second level, based on an appropriate base, including general didactic principles (Matveev, 1977, 2010; Platonov, 1997, 2004; Gaverdovsky, 2007).

Special principles as basic attitudes, provisions, rules that determine the content of wrestlers' sports training reflect stable connections between its various components natural inclinations and the possibilities of their implementation in order to achieve a high level of sportsmanship; between the factors of influence on the body of the athlete of the wrestler and his adaptive reactions; between their various physical qualities, sides of training and the structure of competitive activity, etc. [2, 9]

At the same time, the special principles highlighted in the special literature do not strictly standardize the structure and content of the training of athletes and wrestlers, but are only generalizations and methodological guidelines that ensure the rational provision of training for athletes, translating it onto a solid scientific platform (Matveev, 1999; 2004, 2015).

Moreover, and it is quite natural that in some scientific works, which reflect the basic provisions of training in wrestling, control of movements, the development of motor qualities, in one form or another, there is a transition from general didactic principles to rules and attitudes of a social nature, the desire to realization of the corresponding objective laws relating to one or another section of the training of wrestlers, motor quality or technical and tactical action $[2,6,9]$.

At the same time, the orientation towards such principles as striving for higher achievements, in-depth specialization, the continuity of the training process, the cyclical nature of the training process, etc., is clearly visible $[3,7,8]$.

At the same time, there is also an insignificant tendency in the special literature on the training of wrestlers, where the authors rely on such fundamental principles as the unity and relationship of the structure of competitive activity and the structure of training, the unity of general and special training $[1,8,9]$.

Moreover, there is limited information about the possibilities of such important principles as in-depth specialization, variability of loads, the unity and interconnection of the training process with extra-training factors $[2,5]$.

Practically out of attention is such an important principle for wrestling as the relationship between the training process and injury prevention $[3,4,5,6,7]$. 
This situation is a natural consequence of the desire in the training process to rely on traditions that have developed in an extremely diverse and, in general, effective sports practice, neglect of the basic provisions of the general theory of training athletes, the need to constantly improve knowledge based on combining the achievements of practice with the development of a general theory of training athletes, achievements of related scientific disciplines.

At the same time, the use of the principles of each level (general didactic, general, special for the type of struggle) or different principles related to one of the levels cannot be distinguished by strict selectivity and independence of their reflection in the training process. Separate content components of the system of sports training often presuppose the implementation of the provisions characteristic of different principles, ensuring the complexity of the impact on the body of those involved. The desire to single out absolutely independent, mutually exclusive principles in such a complex and multifactorial process as the sports training of wrestlers in general or in a variety of particular processes associated with the formation of various aspects of sportsmanship, the development of certain motor qualities, components of competitive activity, etc., suffer from artificiality and onesidedness (Matveev, 1999; Gaverdovsky, 2007).

Of particular importance in the formation and development of strength training of athletes-wrestlers belongs to special principles, in the development of which the fundamental works of L.P. Matveev (1964, 1997, 1999, 2010) played an important role. Noting that sports training, as a pedagogically organized process, is extended, first of all, by general pedagogical principles, since they concentratedly reflect the most general starting positions that are valid for any educational activity, L.P. Matveev demonstrates the need to supplement them with a set of special principles based on patterns that reflect the specifics of sports training (Matveev, 1977).

L.P. Matveev, relying on the regularities objectively manifested in the system of sports training, identifies a number of basic principles characteristic of this area of knowledge and practical activity:

- orientation to the maximum of achievements;

- in-depth specialization and individualization;

- unity of general (basic) and special training;

- continuity of the training process;

- gradualness and tendency to maximum loads;

- undulating dynamics of loads;

- cyclicity of the training process (LP Matveev, 1964, 1977).

When revealing the rationale for the advancement and content of these principles, he provides convincing material that reflects the natural nature of the processes and phenomena that underlie them. In subsequent years, the content of the principles put forward by L.P. Matveev received an exceptionally wide and constantly increasing empirical base and the corresponding theoretical generalizations (Meerson, 1981; Ozolin, 1984; Zhelyazkov, 1986; Platonov, 1997; Dryukov, 2002; etc.).

The focus on achieving maximum achievements and in-depth specialization and individualization reflects the very essence of sport, which distinguishes it from many other spheres of human activity. Sports training is focused on the maximum possible result, without which sports performance and competitiveness cannot be ensured.

However, with the growth of achievements and the intensification of competition, it became clear that the striving for universalism is a constraining factor that does not give the opportunity to fully reveal the natural inclinations of an athlete. At the beginning of the 1920s, a prominent sports specialist V.V. Gorinevsky noticed: "You 
cannot be a sports generalist, that is, give yourself up to all kinds of sports indiscriminately. Such universality is dilettantism, which does not allow individuality to manifest itself in all its depth" (Gorinevsky, 1988). The entire subsequent history of sports, including the achievements of sports science, is focused on in-depth specialization practically throughout the entire sports career. Even at the early stages of longterm training, the solution to the issues of versatile physical development, general (basic) fitness should not be solved at the expense of solving the problems of in-depth specialization in a specific sport (Matveev, 2010; Platonov, 2015).

The implementation of the principle of unity of general (basic) and special training in the development of strength qualities involves the use of the widest range of exercises of general training, auxiliary, special training and competitive nature. General training and auxiliary exercises in the process of strength training, providing a variety of motor actions, the manifestation of different types of strength, the manifestation of strength qualities in concentric, eccentric, isometric, plyometric and ballistic modes of muscular activity create the necessary basis for a versatile special training, the use of means of special training and competitive character (Platonov, 2017). Various types of jumps, pull-ups on the bar, push-ups in the supine position or on the uneven bars, exercises with a barbell, dumbbells, kettlebells, various throws of medicine balls, coordination exercises, basketball games, football with free rules and tough confrontation create the necessary prerequisites for increasing efficiency specially - training and competitive exercises. However, it is necessary to ensure that the content of strength and speed-strength training of a general orientation does not conflict with the content of special training, factors that ensure effective competitive activity. For example, if you use an excessive amount of general preparatory strength training, focused on muscle hypertrophy and the development of the so-called "slow strength", as recommended by a number of specialists striving to bring athletes specializing in Olympic sports with a high importance of strength readiness to the training methodology, experience gained in bodybuilding (Bompa et al., 2003; Stone et al., 2008), such training can cause serious harm, negatively affecting not only sports technique, coordination and speed capabilities, endurance, but also speed strength ( Earle, Beachle, 2008; Gamble, 2013). Such recommendations and the corresponding sports practice grossly distort the content of the very principle of the unity of general and special training (Matveev, 2010).

Insufficient attention to general and auxiliary strength training, excessive enthusiasm for special training and competitive exercises lead to instability of motor actions, instability of muscles, tendons, ligaments to injuries. Another problem of narrowly focused special training is psychological fatigue, "burnout", decreased motivation to go in for sports. Therefore, in the long-term plan, the "multisport" experience focused on youth sports is important (Brewer, 2009), and in the process of the annual training of high-class athletes, the continuity of the use of general training, auxiliary, specialpreparatory and competitive means for the development of strength qualities (Harre, 1982; Vaytsekhovsky, 1985; Matveev, 1999; Platonov, 2004; Gamble, 2013, etc.).

The principle of advanced specialization is closely related to the principle of individualization. This is natural, since only if the specialization corresponds to the individual capabilities of athletes, one can count on successful training (Matveev, 1977).

The need for an organic relationship between the versatile development of an athlete with his special training is reflected in the principle of the unity of general and special training. The most important problem in the implementation of this principle is taking into account the interaction between general (basic) 
and special components of training. These interactions can be positive, when the development of basic qualities or properties enhances special ones, or negative, when the components of general training can negatively affect special ones (Matveev, 1977). The need for general (basic) training is obvious, since it is impossible to solve many problems with purely special means that ensure both the effectiveness of special training and the level of sports training (Vaytsekhovsky, 1985; Platonov, 2004).

However, it should be borne in mind that excessive basic training can seriously limit the prospects of an athlete in relation to the most important components of special training. For example, excessive amounts of aerobic work aimed at the development of the so-called general endurance can negatively affect the structure of the speed types of muscle fibers, negatively affect the speed and strength capabilities of athletes (Swank, 2008; French, 2016). Excessive passion for strength training, focused on muscle hypertrophy, disrupts the technique of movements, reduces the level of coordination and speed abilities, endurance (Platonov, 2017).

The principles of the continuity of the training process, gradualness and tendencies towards maximum loads are based on a number of patterns associated with the development of adaptation of the body in response to training and competitive loads, such as fatigue, recovery, supercompensation, urgent and delayed training effect, adaptation, deadaptation, overadaptation, readaptation. To date, a huge array of empirical knowledge and theoretical generalizations has been accumulated, contributing to the effective use of these principles in the process of sports training.

The principle of waveform and dynamics of loads and the cyclicity of the training process is ensured by: a balance between training loads that stimulate the processes of adaptation of the body of athletes and the conditions for their effective course; concentration in time and the optimal combination of loads of a certain orientation; management of the processes of fatigue, recovery and the formation of a delayed training effect; organic relationship of the training process and competitive activity; prevention of overwork, overstrain of functional systems, overtraining and injury (Matveev, 1964, 1977, 1999).

V.N. Platonov in a series of fundamental works on the general theory of sports and sports training $(1984,1997,2004,2015,2017)$, following L.P. Matveev (1964, 1977, 1999, 2010), draws a clear boundary between general didactic principles and their implementation in the practice of sports training and special principles that predetermine the specific methodology of sports training. Special principles, as guiding ideas, setting positions are the basis, the foundation of the theory and methodology of sports training. In their content, the principles are based on special patterns - stable and recurring connections between natural inclinations and the possibilities of achieving a high level of skill in a particular sport; between the means and methods of influencing the athlete's body and his response reactions of an urgent, total, cumulative and delayed nature; between different motor qualities (speed, strength, coordination, dexterity, flexibility, endurance) and types of training (physical technical, tactical, psychological, general, auxiliary special, etc.) (Platonov, 2017).

Critical specific principles based on a solid scientific foundation and tested by good sporting practice include:

- the principle of maximization and harmonization;

- the principle of compliance of the training content with the age and gender characteristics of the athlete;

- the principle of the training process continuity;

- the principle of unity of general (basic) and special training; 

loads;

- the principle of variability of training

- the principle of wave-like training loads;

- the principle of organic interconnection of the training process with the environment (extra-training factors);

- the principle of compliance of the content of the training process with the prevention of injuries and occupational diseases (Platonov, 2015, 2017).

The need for the development, continuous development and implementation of specific principles in practice is presented in many works by other world-famous specialists in the field of theory and methods of training highly qualified athletes (Ozolin, 1970; Harre, 1971; Vorobiev, 1987, 1989; Zhelyazkov, Dasheva, 2002, 2011; Gaverdovsky, 2007; and others).

A.N.Vorobyov, two-time Olympic champion in weightlifting, a prominent specialist in the theory and methodology of sports training, throughout his career has successfully combined research work with the training of highly qualified athletes. $\mathrm{He}$ summarized his knowledge and practical experience in a large number of articles, several textbooks and monographs. The question of the principles of sports training in a generalized form he outlined in the work "Training, working capacity, rehabilitation", which was published in 1989 in the Moscow publishing house "Physical culture and sport". Noting the need to substantiate the principles of sports training, on the basis of objectively existing regularities, proven provisions and rules, A.N. Vorobyov noted that the basis of successful sports training is the complex use of principles as an integral part of the theory and methodology of training athletes. None of the principles was a priority, but only their parallel use can lead to success (Vorobyov, 1989).

A.P. Bondarchuk (2005) introduced and substantiated the principle of combining selectivity, variability and complexity, reflected in various types of combination of training loads during a training macrocycle. The implementation of this principle, according to the author, plays an important role in ensuring versatile training, accelerating the process of entering the state of sports form and keeping it.

Considering the search for ways to improve the process of periodization of annual training with a focus on mastering a wide calendar of competitions, A.P. Bondarchuk (2005) put forward the principle of a variety of methods for constructing periods of sports form development as significantly supplementing and developing the content of the principle of interrelation of gradualness and tendency to extreme loads, as well as the principle of cyclicity of the training process (Matveev, 1977).

At the same time, A.P. Bondarchuk introduced the principle of stage-complex development of sports form, according to which athletes alternately enter the state of sports form in general training exercises, and then sequentially in special-training, speciallydeveloping and competitive ones (Bondarchuk, 2005) ... However, this principle is in conflict with the generally accepted content of the concept of "sports form", which should be understood as the highest level of training for competitive starts, and not the level of fitness in relation to a particular group of exercises (Matveev, 1999, 2010; Platonov, 1997, 2015 and etc.).

In the development of the regularity about the "transfer" of training (Harre, 1982; Matveev, 1999), A.P. Bondarchuk (2005) recommends the principle of relationships between different types of exercises in the development of sports form, focusing on the presence of positive or negative transfer or the absence of relationships between the training effect obtained as a result of using various types of general training, special training, specially developing and competitive exercises. This principle is of great importance for optimizing the means and methods of strength training, building the process of developing strength qualities at various stages of longterm and annual training. 
A well-known specialist in the field of theory and practice of movement control and teaching movements and motor actions A.K. Gaverdovsky (2007), while developing the system of principles of sports training, followed the path of specification and systematization of general didactic ideas and principles established in general and sports pedagogy. In particular, the author notes that the constant reproduction of the well-known principles of didactics (accessibility, strength, systematicity, sequence of learning, consciousness and activity, etc.) should be supplemented by their concretization and expansion in relation to changes in the general methodology of science and the development of such areas as the system approach, the theory of functional systems, the theory of adaptation, etc. It is equally important to ensure the development of principles, taking into account the expansion of the empirical base of various areas of sports science, identifying and clarifying the patterns that ensure the optimization of the process of sports training.

In contrast to specialists who recommend supplementing the principles of general didactics with specific principles that reflect the patterns of sports training and bring them to a set of rules that ensure its effectiveness (Harre, 1971; Matveev, 1977, 2010; Platonov, 1997, 2015; Zhelyazkov, Dasheva, 2011) Gaverdovskiy (2007) recommend a set of principles based on the transformation of social didactic principles, taking into account the requirements dictated by the laws that determine the effectiveness of sports training and competitive activity. With this approach, didactic principles in their content move from a "global" understanding, weakly connected with a specific activity, to a "targeted", selective and analytical purpose of individual principles in their totality. With this in mind, the names are concretized and the content of individual principles is revealed, including:

- the principle of expediency and practicality;
- principle of training and current validity;

- the principle of controllability and accountability;

- the principle of consistency and orderliness;

- the principle of regularity and gradualness;

- the principle of dynamic dynamism and progression;

- principle of redundancy and reliability;

- the principle of perceptual and semantic "visualization";

- the principle of upbringing education and positive motivation;

- the principle of accessibility and challenging difficulty;

- the principle of necessary adaptability and independence;

- the principle of strength and plasticity;

- the principle of consciousness and activity with the leading role of the coach;

- the principle of individualized learning in a team;

- the principle of unity of tradition and innovation;

- the principle of the unity of theory and practice (Gaverdovsky, 2007).

Many of these principles are widely used in the practice of training athletes, and are reflected in the form of rules and guidelines in the specialized literature (Bompa et al., 2003; Willmore, Costill, 2004; Gaverdovsky, 2007, Baechle, Earle, 2008). However, a number of them, which are fundamentally important for modern sports training, are outside the necessary attention and do not find proper reflection either in special literature or in the practical activities of coaches.

Some specialists, the range of scientific interests of which is mainly associated with a specific kind of sport, type of training or the methodology for the formation of certain aspects of sportsmanship or the development of motor qualities, concretize the principles in relation to a certain part of the training process. For example, V.V. Kuznetsov (1970, 1975) defines the principles underlying strength 
training of athletes in the form of specific features of the methodology for the development of strength qualities. Among them:

- biomechanical correspondence of means and methods used in the development of strength, the specificity of competitive exercises;

- correspondence of the modes of muscular activity to the specificity of competitive exercises;

- balance of volumes of competitive, special and specially training exercises;

- compliance of the methodology for the development of strength qualities with the individual characteristics of an athlete;

- the relationship between the development of strength qualities with the formation of other sides of training.

In the works of some specialists, general didactic and special principles are brought together into a single group. N.G. Ozolin, one of the leading experts in the field of theory and practice of sports of the twentieth century, in his fundamental work "Modern system of sports training" (Ozolin, 1970) highlighted a separate section "Principles of sports training", noting that in relation to sports training not only the development of a certain content of established pedagogical principles is required, but also the inclusion of special principles that reflect the features of the training process, the regularities of the formation of different aspects of sportsmanship. The following are recommended as the main principles: specialization, comprehensiveness, consciousness, gradualness, repetition, visualization, individualization (Ozolin, 1970).

All these principles are interconnected and interdependent, and only their parallel implementation determines the effectiveness of the training process. Rational training requires the unity of specialization and versatility, gradualness and repetition, conscientiousness and clarity. The application of any of the principles requires an individual approach (Ozolin, 1970).
The work of N.G. Ozolin also shows the capabilities of each of the principles in managing the development of various aspects of athletes' fitness (technical, physical, tactical, moral-volitional, integral) on the basis of biological and psychological patterns of development of fitness and fitness of an athlete (Ozolin, 1970) ...

A similar approach to the development and use of the principles of sports training is implemented in the generalizing works of famous German specialists - representatives of the school of the former GDR - D. Harre, G. Schnabel, D. Krug, A. Borde, G. Thiesse, etc. In the works of these authors $(1993,1997$, 2012, 2016) special laws, rules and attitudes are implemented both through special principles and by expanding the content of the principles of general didactics, applying their provisions to the content of sports training.

However, L.P. Matveev (1999, 2010), unlike many specialists, does not allow mixing the principles of general didactics, theory and methodology of physical education and special principles of sports training, clearly indicates the place of each of these groups of principles in the practice of training athletes.

The didactic principles that have developed in the field of general pedagogy (consciousness, activity, clarity, accessibility, systematicity, etc.) reflect the universal laws of training and education, which cannot but apply to the process of sports training.

The principles developed by the theory and methodology of physical education (continuity, systemic mode of work and rest, building up developmental and training influences, etc.) reflect the general laws of physical education, are also valid in relation to sports training, but only to the extent that it is only one of the varieties of the physical education system (Matveev, 2010).

However, neither the general didactic principles, nor the principles developed by the theory and methodology of physical education reflect the set of regularities specific to the process of sports training. Specific regularities 
linking various training factors (means, methods, external influences, etc.) with the body's reactions to their impact, reflecting the connections between a variety of specific reactions, processes and phenomena, formalized in the form of principles, ensure the objectivity and effectiveness of activities in the field of training athletes (Matveev, 2010).

Cognition of patterns and development of special principles of sports training has a long history. And the current state of knowledge in this area is a reflection of the versatile experience of training athletes, the achievements of various schools of sports, a huge array of knowledge accumulated by the theory of sports and sports training, special branches of various biological, medical and social disciplines (Matveev, 1999; Platonov, 2004, 2015; Gaverdovsky, 2007).

However, special principles, developed within the general theory of athletes' training, require concretization, expansion and clarification in relation to various sports, various aspects of training or motor qualities. This activity can be presented in the form of disclosing the potential of the established principles of the general theory of training in relation to certain sections of training or in the form of special principles of a lower hierarchical level inherent in a specific type, section or side of sports training.

\section{Conclusions.}

1. In the study and development of numerous specialists, general and special principles for strength training of athletes, their author's diversity is observed, as well as their interdependence and the need for practical application.

2. The results of the studied specialized literature show that it is obvious that there is a need for a wide coverage of new principles and ways of their implementation in the strength training of wrestlers, their adaptation to the requirements, tasks, means and methods that deny the specifics of wrestling.

3. A vertical should be created, including general didactic principles, as the basis of special principles that reveal the capabilities of athletes in relation to high-performance sports and specific for a particular type of wrestling, principles that allow to place the most significant accents for a specific type of martial arts.

4. The current state of knowledge on general didactic and specialized principles in the field of theory and methodology of training athletes specializing in wrestling, as well as trends in their further development, should progressively influence the development of strength abilities, as well as the qualifying success of wrestlers of various styles.

\section{References:}

1. Бойко В.Ф., Данько Г.В. (2004). Физическая подготовка бориов. Киев: Олимпийская литература. $300 \mathrm{c.}$

2. Васильков А.А. (2008). Теория и методика спорта. Ростов на Дону: Феникс. 381 с.

3. Гожин В. (2005). Теоретические аспекты техники и тактики спортивной борьбы. Монография. Москва: Физкультура и спорт.

4. Ерегина С.В., Тарасенко К.Н. (2007). Комплексная оценка физической подготовленности дзюдоистов. В: «Детский тренер», № 2.

5. Зекрин Ф.Х. (2006). Динамика совериенствования средств общей и специальной физической подготовки дзюдоистов на различных этапах многолетней тренировки. В: «Детский тренер», № 2.

6. Иванов И.И, Кузнецов А.С, Самургашев Р.В, Шулика Ю.А. (2004). Борьба греко-римская [GrecoRoman wrestling]. Ростов-на-Дону: Феникс. 800 с. 
7. Карамов С. К. (2009). Корейский рукопашный бой [Кorean hand-to-hand combat]. Москва: Современная школа. 169 с.

8. Курамшин Ю.Ф. (2004). Теория и методика физической культуры. М.: Советский спорт. $219 \mathrm{c}$.

9. Левицкий А.Г. (2003). Управление процессом подготовки дзюдоистов с учетом уровня индивидуальной готовности к соревновательной деятельности. Автореф. дис. д-ра пед. наук. СПб.

10. Максименко А.М. (2009). Основы теории и методики физической культуры. Москва: Физкультура и спорт. 544 с.

11. Манолаки В.Г. (1993). Методика подготовки дзюдоисток различной квалификации. Монография. Санкт-Петербург.

12. Манолаки В.Г. (1993). Оптимизация воздействия силовых и скоростно-силовых нагрузок в проиессе многолетней подготовки дзюдоисток различной квалификации: Диссертация доктора наук. Санкт-Петербург.

13. Манолаки В.Г. (1990). Педагогический контроль за уровнем подготовленности квалифищированных дзюдоисток на этапе спортивного совершенствования: Автореф. канд. дисс. Л.

14. Манолаки В.Г. (2003). Спортивная борьба - теория и методика. Кишинев: Центральная типография.

15. Никитушкин В.Г. (2013). Система подготовки спортивного резерва. Москва: Просвещение.

16. Свищев И.Д. (2004). Актуальные проблемы спортивной борьбы. Москва: Спорт Универ Пресс. 75 с.

17. Холодов Ж.К. (2012). Теория и методика физического воспитания и спорта. Москва: Издательский центр «Академия». 480 с.

18. Шулика Ю.А. (2006). Дзюдо (система и борьба). Ростов на Дону: Феникс. 800 с.

19. Шулика Ю.А. (2006). Дзюдо. Базовая технико-тактическая подготовка для начинающих. Ростов на Дону: Феникс. 240 с. 